\title{
Visual aids for support teachers in learning Debora
}

\author{
${ }^{* 1}$ Exaudi Sirait, ${ }^{1}$ Lolyta Damora Simbolon, ${ }^{1}$ Switamy Angnitha Purba, ${ }^{1}$ Ady Frenly \\ Manullang \\ ${ }^{1}$ Universitas HKBP Nommensen Pematangsiantar, Sumatera Utara,Indonesia \\ *Email : deboraexaudisirait@uhnp.ac.id
}

\begin{abstract}
Learning media in general is a tool for teaching and learning. Everything that can be used to stimulate the thoughts, feelings, attention and abilities or skills of students so as to encourage the learning process. This limitation is quite broad and includes the understanding of resources, environment, people and methods used for learning / training purposes. Barriers to the use of teaching aids in supporting student interest in learning, obstacles include: conditioning students' attention to learning with teaching aids, teacher learning methods that tend to be less varied so that students are less enthusiastic in learning if the teacher is monotonous, the teaching aids available in schools are incomplete, making teaching aids in accordance with the material and student input is difficult, the minimum time to prepare learning with teaching aids.
\end{abstract}

\section{Keywords : Visual aids, students, teachers}

\begin{abstract}
Abstrak
Media pembelajaran secara umum adalah alat bantu proses belajar mengajar. Segala sesuatu yang dapat dipergunakan untuk merangsang pikiran, perasaan, perhatian dan kemampuan atau ketrampilan pelajar sehingga dapat mendorong terjadinya proses belajar. Batasan ini cukup luas dan mendalam mencakup pengertian sumber, lingkungan, manusia dan metodeyang dimanfaatkan untuk tujuan pembelajaran / pelatihan. Hambatan pada pendayagunaan alat peraga dalam menunjang minat belajar siswa, hambatan meliputi: mengkondisikan perhatian siswa terhadap pembelajaran dengan alat peraga, metode pembelajaran guru yang cenderung kurang bervariasi hingga siswa kurang antusias dalam belajar jika pengajaran guru yang monoton, alat peraga yang tersedia di sekolah kurang lengkap, membuat alat peraga yang sesuai dengan materi dan karakteristik siswa dirasa sulit, minimnya waktu mempersiapkan pembelajaran dengan alat peraga.
\end{abstract}

\section{Kata Kunci : Alat Peraga, Siswa,Guru}

\section{PENDAhuluan}

Umumnya alat peraga matematika digunakan untuk memastikan apakah rumus matematika yang ada benar rumusannya atau tidak, perhitungan matematika yang memiliki rumus seperti phytagoras, pangkat akar, sigma, rumusan luar, keliling, diameter,desimal dan masih banyak lagi perhitungan serta perumusan matematika yang mungkin belum kita ketahui. Media pembelajaran secara umum adalah alat bantu proses belajar mengajar. Segala sesuatu yang dapat dipergunakan untuk merangsang pikiran, perasaan, perhatian dan kemampuan atau ketrampilan pelajar sehingga dapat mendorong terjadinya proses belajar. Batasan ini cukup luas dan mendalam mencakup pengertian sumber, lingkungan, manusia dan metodeyang dimanfaatkan untuk tujuan pembelajaran / pelatihan. Posisi 
media pembelajaran. Oleh karena proses pembelajaran merupakan proses komunikasi dan jelas. Jika perlu bisa digambarkan diagram alir untuk metode pelaksanaan sama dengan aturan untuk membuat diagram alir dari suatu algoritma.

berlangsung dalam suatu sistem, maka media pembelajaran menempati posisi yang cukup penting sebagai salah satu komponen sistem pembelajaran. Tanpa media, komunikasi tidak akan terjadi dan proses pembelajaran sebagai proses komunikasi juga tidak akan bisa berlangsung secara optimal. Alat peraga adalah komponen integral dari sistem pembelajaran.

\section{METODE PELAKSANAAN}

Metode yang digunakan dalam kegiatan ini adalah ceramah interaktif yang dipilih untuk menyampaikan pelatihan alat peraga yang dilaksanakan dalam tiga tahapan yaitu tahap penjajakan lapangan, tahap implementasi, dan tahap evaluasi. Tahap penjajakan lapangan dimulai dari menentukan peserta pelatihan yaitu guru-guru SMA Trisakti, persiapan berbagai administrasi yang diperlukan, melakukan koordinasi dengan Kepala Sekolah SMA Trisakti, persiapan narasumber yang kompeten dan relevan, serta persiapan jadwal kegiatan. Tahap implementasi berupa paparan menggunakan alat peraga (ceramah), tanya jawab (interaktif), serta praktek alat peraga. Berikutnya tahap terakhir yaitu tahap evaluasi, pada tahap ini kegiatan yang dilakukan yaitu evaluasi terhadap implementasi kegiatan yang telah disusun baik tugas ketua tim pelaksana ataupun anggota tim pelaksana. Adapun tempat dilakukannya sosialisasi alat peraga untuk mendukung pengajaran guru yaitu SMA Trisakti Pematangsiantar.

\section{HASIL DAN PEMBAHASAN}

Sasaran kegiatan ini adalah guru-guru IPA SMA Trisakti. Kegiatan dilaksanakan pada bulan Desember 2018 di Ruangan Laboratorium yang diikuti 20 orang tenaga pendidik. Adapun yang menjadi instruktur dan narasumber dalam kegiatan ini adalah Dosen-dosen Program Studi Matematika, Prodi Fisika,Prodi Kimia dan Prodi Biologi , FMIPA Universitas HKBP Nommensen Pematangsiantar. Metode yang digunakan dalam kegiatan ini adalah ceramah interaktif yang dipilih untuk menyampaikan pelatihan, dimulai dengan pembukaan yaitu doa dan perkenalan. Dilanjut ke tahap inti ceramah dari masing-masing narasumber dimana masing narasumber di beri waktu maksimal 50 menit untuk pemaparan, kemudian dilanjut dengan sesi tanya jawab dan untuk penutupan diakhiri dengan praktek alat peraga.

\section{KESIMPULAN}

Jadi alat peraga ini berperan sebagai pendukung proses belajar mengajar matematika menjadi lebih mudah, tanpa harus memiliki mind set sulit atau pun membingungkan. Karena kebanyakan murid berkomentar matematika adalah pelajaran yang sulit dimengerti dan membingungkan. Mereka mengungkapkan pernyataan tersebut kemungkinan karena merasa dipaksa untuk memahami matematika yang mungkin agak sulit dimengerti berdasarkan perhitungan yang menggunakan rumusan matematika, sehingga mereka tidak menyukai pelajaran matematika. Untuk menanggulangi permasalahan murid yang tidak menyukai pelajaran matematika dapat kita minimalisir dengan menggunakan metode bermain dan belajar dengan alat peraga matematika sebagai alat peraga pendukung suksesnya proses pembelajaran. Dengan metode ini murid menjadi menikmati pelajaran dan juga dapat memahami pelajaran matematika yang disampaikan secara berkala. 


\section{UCAPAN TERIMAKASIH}

Ucapan terima kasih dihaturkan kepada Rektor Universitas HKBP Nommensen Pematangsiantar beserta staff nya yang telah mengizinkan kami turut berpartisipasi dalam kegiatan pengabdian kepada masyarakat. Ucapan yang sama kami tujukan untuk Dekan FMIPA dan Ketua Program Studi Matematika Universitas HKBP Nommensen Pematangsiantar. Terima kasih juga kami sampaikan kepada Ketua UPT LPPM Universitas HKBP Nommensen Pematangsiantar beserta staff nya yang selalu membantu kami dalam sisi administratif. Selanjutnya kami juga mengucapkan terima kasih kepada Kepala Sekolah SMA Trisakti, Staff pengajar, dan para siswa/siswi IPA SMA Trisakti karena atas bantuannya pengabdian kepada masyarakat ini dapat dilaksanakan dengan baik dan lancar.

\section{DAFTAR PUSTAKA}

Ade, Sanjaya. 2011. Model-model Pembelajaran. Jakarta: Bumi Aksara.

Afnan, Muhammad. 2016. Pendayagunaan Alat Peraga dalam menunjang minat belajar siswa Kelas V SD Negeri Purbayan 02.

Depdiknas. Undang-undang RI Nomor 20 Tahun 2003 tentang Sistem Pendidikan Nasional Harliastuti, Ekoresmi, Budi Murtiyasa, dan Sofyan Anief. 2012. Pengelolaan Alat Peraga

dalam Pembelajaran Matematika di Sekolah Menengah Pertama Negeri 2 Karanganyar. Naskah. Publikasi. Surakarta: Universitas Muhammadiyah Surakarta

Iwan, Ade. 2016. Alat Peraga dan Media Pembelajaran. Diakses pada 16 Agustus 2018

Rahmiga, Suci. 2017. Kurangnya Sarana dan Prasarana Belajar di Sekolah. Jurusan Teknologi Pendidikan.

Soetjipto. 2004. Profesi Keguruan. Rineka Cipta. Jakarta 